Copyright ( 2020 University of Bucharest Printed in Romania. All rights reserved

ISSN print: $1224-5984$

ISSN online: $2248-3942$
Rom Biotechnol Lett. 2020; 25(1): 1178-1185 doi: $10.25083 / \mathrm{rbl} / 25.1 / 1178.1185$

Received for publication, November, 20, 2018

Accepted, June, 29, 2019

Original paper

\title{
Valorification as functional ingredients of some - by-products from dietary supplement processing
}

\author{
NASTASIA BELC ${ }^{1}$, LIVIA APOSTOL ${ }^{1 *}$, GABRIELA VLĂSCEANU ${ }^{2 *}$, MOȘOIU CLAUDIA ${ }^{1 *}$ \\ TEODORA MANASIA ${ }^{1}$, VALENTIN VLĂDUT ${ }^{3}$, SANMARTIN ÁNGEL MARTÍNEZ ${ }^{4}$
}

${ }^{1}$ National Institute of Research \& Development for Food Bioresources - IBA Bucharest, 6 Dinu Vintila Str., 021102, Bucharest, Romania

${ }^{2}$ Hofigal Export - Import SA, 2 Intrarea Serelor Street, Bucharest, Romania

${ }^{3}$ National Institute of Research-Development for Machines and Installations Designed to Agriculture and Food Industry, Bucharest, Romania

${ }^{4}$ National Technological Centre for the Food and Canning Industry CTC, Murcia, Spain

\begin{abstract}
Given the importance of functional food ingredients for healthy food choices, the challenge for food manufacturers is to find suitable and -convenient functional ingredients for the nutritional improvement of bakery products.

In this study, the partially defatted flaxseed, by-product from oil extraction by cold pressing and the alfalfa concentrate, a by-product obtained resulting from dietary supplement "Alfalfa Complex" processing were used as functional ingredients for the enrichment of wheat flour with bioactive carbohydrates (dietary fibers), bioactive proteins, unsaturated fatty acids and minerals. The analysis of the mixtures of wheat flour enriched with different levels of partially defatted flax seeds and alfalfa concentrate has been done in order to demonstrate their functionality in bakery products based especially on wheat flour.

The objective of the present work was to investigate the physicochemical and technological properties of the samples of breads enriched with different levels of partially defatted flax seeds and alfalfa concentrate (5\% alfalfa concentrate, $10 \%$ partially defatted flax seeds and $7 \%$ partially defatted flax seeds with $3 \%$ alfalfa concentrate).
\end{abstract}

Keywords Flaxseed, alfalfa, amino acids, mineral, dietary fiber.

To cite this article: BELC N, APOSTOL L, VLĂSCEANU G, CLAUDIA M, MANASIA T, VLĂDUȚ V, MARTÍNEZ SÁ. Valorification as functional ingredients of some - by-products from dietary supplement processing. Rom Biotechnol Lett. 2020; 25(1): 1178-1185. DOI: $10.25083 / \mathrm{rbl} / 25.1 / 1178.1185$ 


\section{Introduction}

The big challenges of the world, increasing the number of people over 9 billion by 2050 and the limited resources lead to the need of sustainable production while assuring the nutritional security

The bakery products are the basic, most important food for people, for this reason, nowadays, the nutritional values of these products could be enriched using different bioactive compounds such as vitamins, enzymes, minerals, fiber, antioxidants, phytochemicals and so on. (L. APOSTOL et al [2], KIANOUSH KHOSRAVI-DARANI et al [14]; PÎRVULESCU P. et al [16]).

Flaxseed is the seed of the flax plant (Linum usitatissimum L.) (YALÇIN COŞKUNER et al [20]). The production of flaxseed, all over the world, grew rapidly, over the past years. The request for flaxseed refers to oil content, with multiple destinations, including, edible oil with human health benefits. The increasing demand for the flaxseed oil leads to increased oil yield and the quantity of by products ramained after oil processing. (ALAA EL-DIN A. [1]; BEKHIT \& al [3]). The extraction consists in cold pressing the flaxseed and oil extraction. After removing oil, an important quantity of protein and fibres rich defatted flaxseed remains which usually is used in feeding animals and fertilize the ground.

Different authors showed that the composition of the flaxseed is consisting in: $30-41 \%$ fat, $20-35 \%$ dietary fiber, $20-30 \%$ proteins, $3-4 \%$ ash, and $1 \%$ sugars, depending on the external variations from the flaxseed growth location (CARTER [4]; DAUN et al, 2003 [5]). Therefore, in 2013, Bekhit et al [3], have highlighted the potential of improvement of nutritional and functional properties of food products using flaxseed.

Alfalfa (Medicago sativa L.) is primarily used in animal feed, however in recent years it started to be used more often for food, as it is a rich source of easily assimilated minerals (calcium, phosphorus, iron, magnesium, potassium, zinc, copper, selenium, manganese), vitamins (C, K, D, E, U, provitamin A, B1, B2, B6, B12, folic acid/B9, biotin, niacin) and eight essential amino acids (alanine, lysine, arginine, histidine, cysteine, proline, methionine, tyrosine) (E. GAWEŁ et al, 2017 [10]; GAWEL and GRZELAK, 2014 [11]; DAY, 2013 [7]; DAVYS et al, 2011 [6];).

Regarding the alfalfa concentrate, it is another valuable by-product obtained during dietary supplement "Alfalfa complex" processing, by Hofigal Export-Import SA (Bucharest, Romania).

The aim of the present study is to mix the partially defatted flaxseed, by-product from obtained by cold pressing extraction oil, by Hofigal Export-Import SA (Bucharest, Romania), with an alfalfa concentrate, in different proportions, and add them to wheat flour in order to study the improvement of the nutritional and functional values of resulting bread.

\section{Materials and Methods}

\section{Materials}

The materials used in the experiments are: partially defatted flaxseed flour, a by-product obtained during processing the flaxseed oil extraction, alfalfa concentrate flour, a by-product resulted from the processing of the dietary supplement "Alfalfa Complex", whole wheat flour provided by Hofigal Export - Import SA (Bucharest, Romania) (Fig. 1) and Pakmaya Yeast.

\section{Preparation of wheat flour enriched in bioactive compounds types}

Three samples of mixtures from wheat flour, with different proportions of partially defatted flaxseed flour and alfalfa concentrate were obtained. The types of flour mixtures used in this study are presented in Table 1.

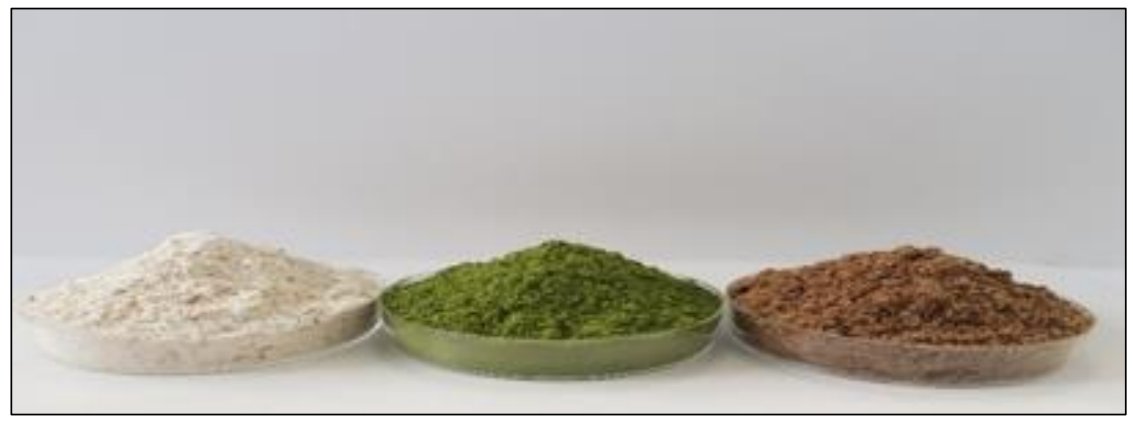

Figure 1. Whole wheat flour, alfalfa concentrate flour and defatted flaxseed flour.

Table 1. Types of flours obtained by addition of partially defatted flaxseed and alfalfa flour

\begin{tabular}{|c|l|}
\hline M & $100 \%$ whole wheat flour \\
\hline 1 & $90 \%$ whole wheat flour $+10 \%$ partially defatted flaxseed \\
\hline II & $95 \%$ whole wheat flour $+5 \%$ alfalfa concentrate \\
\hline III & $90 \%$ whole wheat flour $+7 \%$ partially defatted flaxseed $+3 \%$ alfalfa concentrate \\
\hline
\end{tabular}




\section{Chemical analysis}

Moisture content was determined at $103^{\circ} \mathrm{C}\left( \pm 2^{\circ} \mathrm{C}\right)$ (2 $\mathrm{g}$ test samples) until constant weight was attained (SR 90:2007). The ash content was determined by sample incineration at $525 \pm 25^{\circ} \mathrm{C}$ (SR 90:2007). Total fat content was determined by extracting $5 \mathrm{~g}$ of sample with petroleum ether at $40-65^{\circ} \mathrm{C}$, using a semi-automatic Soxhlet Foss Extraction System 2055 (Foss, Sweden). Total nitrogen (N) and crude protein content (Nx6.25, conversion factor) was determined by the Kjeldahl Method (KjelMaster K-375, Buchi, Germany). The total carbohydrate content was calculated by difference: 100 - (ash content + protein content + fat content + moisture content). The crude fiber content of the samples was determined using a FibrethermGerhardt apparatus. Crude fibers include cellulose, hemicelluloses, and lignin. All experiments were performed in triplicate.

\section{Mineral content analysis}

Mineral content was determined using an atomic absorption spectrophotometer (ContrAA 700; Analitykjena). Total ash was determined by incineration at $550^{\circ} \mathrm{C}$, in an oven. Analysis was performed using an external standard (Merck, multi element standard solution) and calibration curves for all minerals were obtained using 6 different concentrations. Dried samples were digested in a mixture of concentrated $\mathrm{HCl}$.

\section{Amino acid content analysis}

For the analysis of amino acid content, samples were hydrolyzed at $100-120^{\circ} \mathrm{C}$ in $6 \mathrm{~N}$ hydrochloric acid for 22-24 hours under vaccuum.

After evaporation to dryness of hydrochloric acid, the dried residue was diluted using $4 \mathrm{mM}$ stock solution of Norleucine.

The chemical score of alfalfa concentrate flour was calculated according to FAO/WHO (1985) as follows:

$$
\text { Chemical Score }=\frac{m g / g \text { of essential amino acid in test protein }}{m g / g \text { of essential amino acid reference protein }} \times 100
$$

\section{Bread quality}

\subsection{Specific volume measurement}

To determine the bread specific volume, each loaf was weighed and its volume was determined by the rapeseed displacement method (SR 91:2007 [18]). Data were reported as the mean of three measurements of freshmade loaf bread. It is expressed in $\mathrm{g} / \mathrm{cm}^{3}$.

6.2. Porosity measurement content consists in determining the total hole's volume of a known volume of core bread, knowing its mass and density. It is expressed in \%.

6.3. Elasticity content measurement consists in pressing a standardized piece of crumb bread, determined by measuring it at a given time and return to its original shape after removing the pressing force. Crumb elasticity is expressed in percent meaning the ratio between the height expressed in \% by pressing and return, and the initial height of the cylinder crumb bread.

6.4. Determination of organoleptic characteristics

It was determined the "Bread score" based on the quantification of a set of organoleptic characteristics, reported to a standard volume of $400 \mathrm{~cm}^{3} / 100 \mathrm{~g}$ and $85 \%$ porosity, method validated by IBA Bucharest.

Samples of bread were subjected to analyzes by the "Score Bread" method two hours after processing and cooling.

Table 2. Organoleptic characteristics and theirs scores for calculating the bread marks

\begin{tabular}{|l|c|}
\hline \multicolumn{1}{|c|}{ Indicator } & Scores \\
\hline Volume & 24 \\
\hline Marginal crack height & 7 \\
\hline Crust color & 7 \\
\hline Crumb appearance & 10 \\
\hline Porosity & 20 \\
\hline Elasticity & 20 \\
\hline Aroma & 12 \\
\hline Total & 100 \\
\hline
\end{tabular}

\subsection{Moisture content measurement}

Moisture content of the bread crumb was determined at $103^{\circ} \mathrm{C}\left( \pm 2^{\circ} \mathrm{C}\right)$ until constant weight for each measurement. Approximately $5 \mathrm{~g}$ of crumb were taken from central slices of the loaf. Data are reported as the mean of three measurements, each one performed on a freshmade loaf.

6.6. Acidity content measurement consists of aqueous extract of bread titration with $0.1 \mathrm{~N} \mathrm{NaOH}$ solutions in the presence of phenolphthalein, as indicator. The acidity was expressed in degree of acidity.

\section{Statistical Analysis}

All analyses were performed in triplicate and the mean values with the standard deviations were reported. Microsoft Excel 2003 Program was used for statistical analysis of the data with a level of significance set at 95\%. Analysis of variance (ANOVA) followed by Tukey's test was used to assess statistical differences between samples. 


\section{Results and Discussion}

\section{Chemical analysis of the wheat flour and partially defatted flexseed mixture}

Partially defatted flaxseed flour enriched with alfalfa concentrate, for the obtaining of a value-added wheat flour is an interesting source of enrich the nutritional composition of bread, compared with those obtained from the simple wheat flour. In addition, flaxseed is a rich source of oil: $38-45 \%$ (Daun et al [5]), of $\alpha$-linolenic acid, lignans and phenolic compounds, providing beneficial effects on human's health. (Hall et al [12])

The chemical composition of wheat flour and mixtures wheat flour with partially defatted flaxseed flour and alfalfa concentrate flour are shown in Table 3. The ratios of the different flours incorporated in, are shown in Table 1.

Table 3. Chemical composition of wheat flour and mixtures wheat flour with partially defatted flaxseed and alfalfa concentrate flours

\begin{tabular}{|c|c|c|c|c|c|}
\hline \multirow{2}{*}{ Sample } & \multicolumn{5}{|c|}{$\mathrm{g} / 100 \mathrm{~g}$, based on dry weight } \\
\cline { 2 - 6 } & Total proteins & Ash & Total lipids & Crude fibers & Total carbohydrates \\
\hline M & $11.60 \pm 0.11$ & $0.95 \pm 0.08$ & $1.16 \pm 0.11$ & $2.48 \pm 0.11$ & $86.29 \pm 0.16$ \\
\hline I & $13.92 \pm 0.16$ & $1.46 \pm 0.09$ & $2.81 \pm 0.14$ & $3.32 \pm 0.16$ & $81.81 \pm 0.11$ \\
\hline II & $12.07 \pm 0.13$ & $1.47 \pm 0.09$ & $1.18 \pm 0.11$ & $3.19 \pm 0.14$ & $85.28 \pm 0.15$ \\
\hline III & $13.50 \pm 0.15$ & $1.62 \pm 0.10$ & $2.32 \pm 0.12$ & $3.50 \pm 0.18$ & $82.55 \pm 0.12$ \\
\hline
\end{tabular}

* Results given as: $\mathrm{M} \pm \mathrm{SD}$ (mean \pm standard deviation) of triplicate trials.

As the data from the previous table shows, the enrichment of wheat flour with partially defatted flaxseed flour and alfalfa concentrate enhances the nutritional values of bakery products, especially in crude fibers. Therefore, all three mixtures of flours contain more than 3 grams of crude fibers per $100 \mathrm{~g}$ total.
In this study, the content of some minerals were analysed: calcium $(\mathrm{Ca})$, magnesium $(\mathrm{Mg})$, sodium $(\mathrm{Na})$, potassium $(\mathrm{K})$, iron $(\mathrm{Fe})$ and manganese $(\mathrm{Mn})$, as well as an additional two essential traces of zinc $(\mathrm{Zn})$ and copper (Cu) (Table 4).

Table 4. Mineral content of wheat flour and mixtures wheat flour with partially defatted flaxseed flour and alfalfa concentrate flour

\begin{tabular}{|c|c|c|c|c|c|c|c|c|}
\hline \multirow{2}{*}{ Sample } & \multicolumn{7}{|c|}{ Constitutes $(\mathrm{mg} / 100 \mathrm{~g}):$} \\
\cline { 2 - 9 } & $\mathbf{C a}$ & $\mathbf{M g}$ & $\mathbf{N a}$ & $\mathbf{K}$ & $\mathbf{F e}$ & $\mathbf{M n}$ & $\mathbf{Z n}$ & $\mathbf{C u}$ \\
\hline M & $41.50 \pm 0.65$ & $87.20 \pm 0.70$ & $19.50 \pm 1.35$ & $305.30 \pm 1.07$ & $4,78 \pm 0.41$ & $2.52 \pm 0.45$ & $2.10 \pm 0.52$ & $0.45 \pm 0.09$ \\
\hline I & $45.78 \pm 0.68$ & $99.68 \pm 0.78$ & $26.85 \pm 1.70$ & $335,27 \pm 1.11$ & $13,73 \pm 0.61$ & $2.66 \pm 0.48$ & $2.41 \pm 0.54$ & $0.95 \pm 0.14$ \\
\hline II & $145.43 \pm 0.79$ & $122.69 \pm 0.80$ & $18.95 \pm 1.15$ & $405,54 \pm 1.54$ & $5,38 \pm 0.47$ & $2.59 \pm 0.45$ & $2.13 \pm 0.53$ & $0.43 \pm 0.08$ \\
\hline III & $106.85 \pm 0.90$ & $117.23 \pm 0.90$ & $24.32 \pm 1.55$ & $386.42 \pm 1.18$ & $11.40 \pm 0.56$ & $2.66 \pm 0.48$ & $2.34 \pm 0.48$ & $0.78 \pm 0.11$ \\
\hline
\end{tabular}

Thereby, samples I and III fit into the category of iron source raw materials. (The recommended daily iron dose according to Regulation 1924/2006[17], FDA, 2011[9] is $18 \mathrm{mg} / 100 \mathrm{~g}$ product). The calcium content of samples II and III increased more than the double from $41.2 \mathrm{mg} / 100 \mathrm{~g}$ to $145.43 \mathrm{mg} / 100 \mathrm{~g}$, respectively $106.85 \mathrm{mg}$ and the magnesium content increased considerably, compared to flour of wheat.

Figure 2 presents the influence of the addition of partially defatted flaxseed flour and alfalfa concentrate on wheat flour mineral content in regards to iron, potassium, magnesium and calcium.

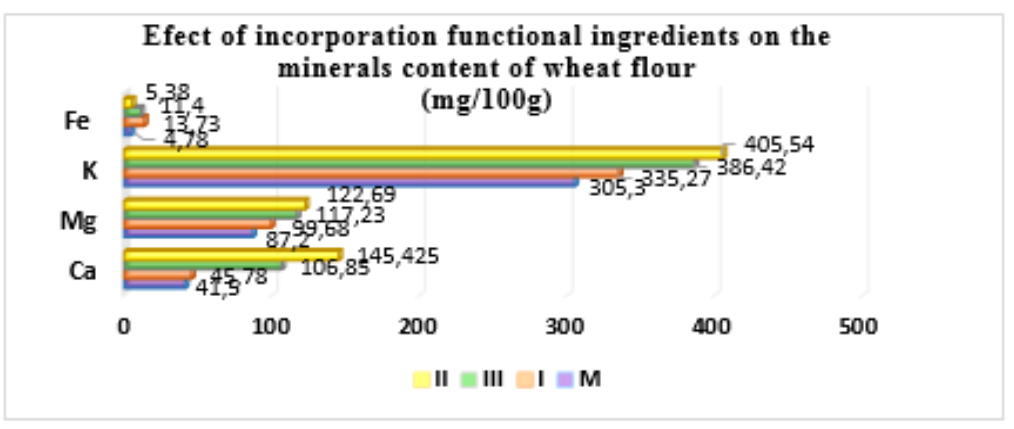

Figure 2. the influence of the addition of partially defatted flaxseed flour and alfalfa concentrate on wheat flour mineral content. 
The calcium, magnesium and potassium content of the partially defatted flaxseed flour is lower than that of the alfalfa concentrate and the sample consisting of the mixture of these 2 ingredients has not a high mineral content. However, the mineral content increases considerably in the three variants of flour mixtures by addition of these ingredients.

The contents of the essential amino acids of the experimental variants studied are presented in Table 5 below.

Table 5. The essential amino acids content of the experimental variants studied

\begin{tabular}{|l|c|c|c|c|c|c|c|c|c|}
\hline \multirow{2}{*}{ Sample } & Lysine & Isoleucine & Leucine & Phenylalanine & Histidine & Valine & Threonine & Methionine \\
\cline { 2 - 9 } & \multicolumn{8}{|c|}{$\mathrm{mg} / 100 \mathrm{~g}$} \\
\hline M & 2.58 & 3.16 & 6.71 & 4.65 & 2.42 & 4.48 & 2.75 & 1.67 \\
\hline I & 2.56 & 3.31 & 6.76 & 4.75 & 2.38 & 4.63 & 2.89 & 1.72 \\
\hline II & 2.62 & 3.16 & 6.69 & 4.62 & 2.37 & 4.47 & 2.79 & 1.67 \\
\hline III & 2.59 & 3.27 & 6.74 & 4.71 & 2.37 & 4.58 & 2.87 & 1.71 \\
\hline
\end{tabular}

In the case of sample I, consisting of a mixture of wheat flour with partially defatted flaxseed flour, the content of some essential amino acids such as isoleucine, leucine, phenylalanine, valine, threonine and methionine is higher than the content of wheat flour. No improvements in the content of lysine and histidine is seen.

For the sample II consisting of $5 \%$ alfalfa flour and $95 \%$ whole wheat flour it could be seen that no improvements in aminoacids content.
Sample III is more valuable in terms of the content of essential amino acids in comparison with wheat flour.

In case of amino acids deficiencies, produced by various diseases or by a protein-poor diet, needed for the synthesis of the body's proteins, essential and non-essential amino acids are needed in certain ratios.

Table 6 shows the content of non-essential amino acids that can be synthesized by the human body.

Table 6. The non-essential amino acid content of the experimental variants studied

\begin{tabular}{|l|c|c|c|c|c|c|c|c|c|c|}
\hline \multirow{2}{*}{ Sample } & Glutamic ac. & Glycine & Serine & Proline & Aspartic ac. & Alanine & Tyrosine & Cysteine & Arginine \\
\cline { 2 - 11 } & \multicolumn{9}{|c|}{$\mathrm{mg} / 100 \mathrm{~g}$} \\
\hline M & 26.25 & 4.26 & 4.67 & 10.52 & 3.35 & 3.37 & 1.61 & 2.36 & 4.34 \\
\hline I & 25.88 & 4.53 & 4.54 & 9.90 & 3.97 & 3.57 & 1.73 & 2.32 & 4.91 \\
\hline II & 25.31 & 4.26 & 4.61 & 10.23 & 3.47 & 3.44 & 1.64 & 2.27 & 4.32 \\
\hline III & 25.42 & 4.45 & 4.54 & 9.91 & 3.85 & 3.56 & 1.72 & 2.28 & 4.73 \\
\hline
\end{tabular}

Whitaker \& Tannenbaum [20] have developed the chemical score procedure to evaluate the ability of a protein source to cover human amino acid needs. The procedure consists in calculating the percent oft each amino acid from tested protein egg protein beeing initially set as standard for evaluation of food proteins.

Related to protein quality, a strong correlation was reported between chemical scores determined in this manner and values obtained through biological assays (Hegsted D.M. [13]).

Below, in Table 7, the chemical scores of selected amino acids from sample I $(90 \%$ wheat flour $+10 \%$ partially flaxseed flour) are presented compared to the standard protein (FAO/WHO/UNU, 1985) [8].

Table 7. Chemical scores of amino acids in the sample I

\begin{tabular}{|l|c|c|c|}
\hline \multicolumn{1}{|c|}{ Amino acids } & Sample I & FAO & Chemical scores \\
\hline Leucine & 6.76 & 6.6 & 102.41 \\
\hline Threonine & 2.89 & 3.4 & 85.06 \\
\hline Valine & 4.63 & 3.5 & 132.31 \\
\hline Phenylalanine & 4.75 & 6.3 & 75.44 \\
\hline Isoleucine & 3.31 & 2.8 & 118.25 \\
\hline Lysine & 2.56 & 5.8 & 44.07 \\
\hline Methionine & 1.72 & 2.2 & 78.36 \\
\hline Histidine & 2.37 & 1.9 & 124.74 \\
\hline
\end{tabular}


Data from table 7 indicates that protein from sample I is a rich source of valine with a chemical score of 132.31, histidine with 124.74 , isoleucine with 118.25 and leucine with 102.41. There are also considerable scores for threonine (85.06) and methionine (78.36). However, it can be seen that lysine is the most limited amino acid (44.07). So, the mixture consisting in $90 \%$ whole wheat flour $+10 \%$ partially defatted flaxseed, is a rich source of valine, histidine and isoleucine, whereas phenylalanine and methionine have the lowest scores.

Table 8 shows the chemical score of amino acids contained in protein from sample II (whole wheat flour and alfalfa concentrate).

Table 8. Chemical scores of amino acids in the sample II

\begin{tabular}{|l|c|c|c|}
\hline \multicolumn{1}{|c|}{ Amino acids } & Sample II & FAO & $\begin{array}{c}\text { Chemical } \\
\text { scores }\end{array}$ \\
\hline Leucine & 6.69 & 6.60 & 101.43 \\
\hline Threonine & 2.79 & 3.40 & 82.09 \\
\hline Valine & 4.47 & 3.50 & 127.64 \\
\hline Phenylalanine & 4.62 & 6.30 & 73.40 \\
\hline Isoleucine & 3.16 & 2.80 & 112.95 \\
\hline Lysine & 2.65 & 5.80 & 45.21 \\
\hline Methionine & 1.67 & 2.20 & 75.80 \\
\hline Histidine & 2.45 & 1.90 & 128.95 \\
\hline
\end{tabular}

Data in Table 8 indicates that the protein from sample II is a rich source of histidine with a chemical score of 128.95, valine with 127.64 , isoleucine with 112.95 and leucine with a score of 101.43. Lysine is the most limited amino acid, followed by methionine and phenylalanine.

From the calculation of the chemical score of protein from sample III, consisting of the wheat flour mixture with both ingredients, it can be seen that the protein of this sample is an important source of valine with a score of
130.81, followed by histidine, isoleucine and leucine. The sample is deficient in lysine (Table 9).

\section{Bread properties}

Table 10 presents the results of experimental bread samples analysis.

The porosity values of the bread samples obtained from the three variants of mixtures are within limits of SR 878/1996 (minimum 66\%) (Fig. 3).

Table 9. Chemical scores of aminoacids in the sample III

\begin{tabular}{|c|c|c|c|}
\hline Amino acids & Sample III & FAO & $\begin{array}{c}\text { Chemical } \\
\text { scores }\end{array}$ \\
\hline Leucine & 6.74 & 6.60 & 102.05 \\
\hline Threonine & 2.87 & 3.40 & 84.53 \\
\hline Valine & 4.58 & 3.50 & 130.81 \\
\hline Phenylalanine & 4.71 & 6.30 & 74.71 \\
\hline Isoleucine & 3.27 & 2.80 & 116.69 \\
\hline Lysine & 2.59 & 5.80 & 44.63 \\
\hline Methionine & 1.71 & 2.20 & 77.56 \\
\hline Histidine & 2.37 & 1.90 & 124.55 \\
\hline
\end{tabular}

Table 10. Physicochemical results for the experimental bread samples

\begin{tabular}{|l|c|c|c|c|c|c|}
\hline \multicolumn{1}{|c|}{ Sample } & $\begin{array}{c}\text { Mass } \\
(\mathrm{kg})\end{array}$ & $\begin{array}{c}\text { Volume } \\
\left(\mathrm{cm}^{3}\right)\end{array}$ & $\begin{array}{c}\text { Porosity } \\
(\%)\end{array}$ & $\begin{array}{c}\text { Elasticity } \\
(\%)\end{array}$ & $\begin{array}{c}\text { Humidity } \\
(\%)\end{array}$ & $\begin{array}{c}\text { Acidity } \\
(\text { grades })\end{array}$ \\
\hline M & 0.512 & 299 & 78.44 & 95 & 44.11 & 1.2 \\
\hline I (10\% flaxseed) & 0.518 & 245 & 71.6 & 92 & 43.59 & 1.6 \\
\hline II (5\% alfalfa ) & 0.517 & 268 & 76.3 & 92 & 45.61 & 1.2 \\
\hline III (7\% flax + 3\% alfalfa) & 0.532 & 233 & 68.1 & 85 & 45.69 & 1.4 \\
\hline
\end{tabular}





Figure 3. Bread samples

The elasticity of bread samples I and II is also according standard (minimum 92).

The acidity of the bread samples, does not exceed 1.6 degrees of acidity which is a value within the normal limits for wheat bread (max. 3.3\%, SR 878-1996 [19]).

According to Table 10 the three experimental bread samples obtained from wheat flour mixtures with the two functional ingredients are acceptable from the point of view of the physic-chemical indicators analyzed.
The method of assessing organoleptic characteristics through "Bread score" is a method used on this study developed by IBA Bucharest.

In the experiments carried out, the score were based on the quantification of a set of characteristics, compared to a standard volume of $400 \mathrm{~cm}^{3} / 100 \mathrm{~g}$ and $85 \%$ porosity.

Table 11 shows the organoleptic characteristics for determining the bread score.

Table 11. Scores obtained by the organoleptic evaluation of bread samples with the "Bread Score"

\begin{tabular}{|c|c|c|c|c|c|c|c|c|}
\hline $\begin{array}{c}\text { Sample/ } \\
\text { Score }\end{array}$ & Volume & $\begin{array}{c}\text { Marginal } \\
\text { crack height }\end{array}$ & $\begin{array}{c}\text { Crust } \\
\text { color }\end{array}$ & $\begin{array}{c}\text { Crumb } \\
\text { appearance }\end{array}$ & Porosity & Elasticity & Aroma & Total \\
\hline M & 18 & 5 & 7 & 10 & 18 & 18 & 12 & 88 \\
\hline I & 15 & 4 & 5 & 7 & 15 & 15 & 10 & 71 \\
\hline II & 16 & 5 & 6 & 8 & 16 & 16 & 8 & 75 \\
\hline III & 14 & 4 & 5 & 6 & 14 & 14 & 7 & 64 \\
\hline
\end{tabular}

Based on the experimental results obtained by the "Bread Score", it confirms the results obtained from the evaluation of the physic-chemical indicators of the bread samples. Thus, almost all bread samples obtained from wheat flour mixed with the two ingredients obtained an acceptable score from this evaluation, except the Sample III which has the lowest score, 64 .

\section{Conclusion}

Alfalfa and flaxseed, as natural ingredients, due to well-balanced nutritional proteins, amino acids, lipids, vitamins, minerals and carbohydrates have been used as a dietary supplement.

In this study the effect of adding these ingredients to the quality of the bread was studied.

The chemical characterization performed in this study proved that the alfalfa concentrate and partially defatted flaxseed is a valuable source of nutritional components, mainly brute fiber content, amino-acids and minerals content.

The experimental bread samples obtained from wheat flour mixtures with the two functional ingredients are acceptable from the point of view of the physic-chemical indicators analyzed. So it can be concluded that bread can be healthy and very attractive when it's enriched with these two ingredients with a functional potential.

Related to the addition of flaxseed and alfa alfa flours, there was used only $5 \%$ of alfa alfa flour instead of $10 \%$ of flaxseed flour, taking into account the previous experiments that demonstrated negative effects on organoleptic characterisctics of bread at over 5\% addition of alfa alfa.

It also can be seen that the mixture between the two ingredients, alfa alfa and flaxseed flours, leads to a lower organoleptic quality than addition of separate ingredients in even higher amount. 


\section{Acknowledgements}

This work was supported by a grant of the Romanian National Authority for Scientific Research and Innovation, CCCDI - UEFISCDI, project number 91/2016 - Romania.

\section{References}

1. ALAA EL-DIN A. BEKHIT \& ALL., Flaxseed: Composition, detoxification, utilization, and opportunities, Biocatalysis and Agricultural Biotechnology, 13 (2018) 129-152.

2. APOSTOL LIVIA., MOSOIU CLAUDIA, IORGA SORIN, SANMARTIN ÁNGEL MARTÍNEZ, Effect of the addition of pumpkin powder on the physicochemical qualities and rheological properties of wheat flour. Romanian Biotechnological Letters (2017), DOI: $10.26327 /$ RBL2017.80

3. BEKHIT, A.E.D., TIAN, X., CARNE, A., HA, M., Effect of Kiwifruit and flaxseed flours on the texture of salami. In: Proceedings of the International Congress of Meat Science and Technology, Izmir, Turkey (2013), 18-23rd, August.

4. CARTER, J.F., Potential of flaxseed and flaxseed oil in Baked goods and other products in human nutrition, Cereal Foods World 38 (1993) 753-759.

5. DAUN, J.K., BARTHET, J.V., CHORNICK, T.L. AND DUGUID, S., 2003. Structure, composition, and variety development of flaxseed. In "Flaxseed in Human Nutrition", (S.C. Cunnane and L.U. Thompson, cds), 2ne, Ed. AOCS Press, Champaign, 1-40.

6. DAVYS, IL., M.N.G., RICHARDIER, F.-C., KENNEDY, D., de MATHAN, O., COLLIN, S.M., SUBTIL, J., BERTIN, E., DAVYS, M.J., 2011. Leaf concentrate and other benefits of leaf fractionation. In: Thompson, B., Amoroso, L. (Eds.), Combating Micronutrient Deficiencies: Food-Based Approaches. CAB International and FAO, Rome, Italy, pp. 338-365.

7. DAY, L., 2013. Protein from land plants - potential resources for human nutrition and food security. Trends Food Sci. Technol. 32, pp. 25-42.

8. Food and Agriculture Organization of the United Nations, World Health Organization \& United Nations University. (1985). Energy and protein requirements.
9. Food and Drug Administration (FDA), www.fda.gov/ regulatoryscience

10. GAWEŁ ELIZA, MIECZYSŁAW GRZELAK, MAGDALENA JANYSZEK. 2017. Lucerne (Medicago sativa L.) in the human diet - Case reports and short reports. Journal of Herbal Medicine 10, pp. 8-16.

11. GAWEŁ, E., GRZELAK, M., 2014. Protein from lucerne in animals supplement diet. J. Food Agric. Environ. 12 (2), pp. 314-319. Agric. Environ. 12 (2), pp. 314-319.

12. HALL, C. TULBEK, M.C.XU, T.Y., Advances in food and nutrition research. Flaxseed (2006) 10.1016/S10434526(06)51001-0

13. HEGSTED, D.M., Assessment of protein quality, in Improvement of protein nutriture. National Academy of Sciences, Washington DC (1974), pp. 64-88.

14. KIANOUSH KHOSRAVI-DARANI, GHOLAMI ZAHRA, GOUVEIA LUISA, Effect of Arthrospira platensis on the shelf life, sensorial andrheological properties of strudel. Romanian Biotechnological Letters, vol. 22, no. 1, (2017), 12250-12258.

15. LAWLESS, H.T., HEYMANN, H., Sensory Evaluation of Food. Principles and Practices, 2nd ed. Springer, New York, NY (2010).

16. PÎRVULESCU PANFIL, BOTĂU DORICA, CIULCA SORIN, MADOŞĂ EMILIAN, ALEXA ERSILIA, GERGEN IOSIF, Biochemical characterization of flour obtained from germinated cereals (wheat, barley and oat), Romanian Biotechnological Letters, vol. 19, no. 5, (2014) 9772-9777.

17. Regulation (EC) No 1924/2006 of the European Parliament and of the Concil of 20 December 2006 on nutrition and health claims made on foods.

18. SR 91:2007. Pâine şi produse proaspete de patiserie. Metode de analiză.

19. SR 878:1996. Pâine de făină de grâu.

20. WHITAKER JR, TANNEBAUM S.R. Food proteins. The Avi Publishing Company Inc., Connecticut (1977).

21. YALÇIN COŞKUNER, ERŞAN KARABABA, Some physical properties of flaxseed (Linum usitatissimum L.), Journal of Food Engineering, 78 (2007), pp. 1067-1073. 